\title{
Kelainan pada Sintesis Hemoglobin: Thalassemia dan Epidemiologi Thalassemia
}

\author{
Retno Dwi Wulandari* \\ Bagian Biomedik Penelitian Biomolekuler Fakultas Kedokteran \\ Universitas Wijaya Kusuma Surabaya \\ *e-mail : retno_dwi_w@yahoo.com
}

\begin{abstract}
Abstrak
Hemoglobinopati meliputi kelainan pada struktur dan gangguan sintesis hemoglobin (thalassemia). Kelainan pada $\mathrm{Hb}$ ini merupakan kelainan gen tunggal yang pada awalnya ditemukan di daerah endemis malaria tetapi saat ini dapat ditemukan di seluruh dunia. Tingkat kelahiran individu homosigot atau heterosigot ganda hemoglobinopati, termasuk thalassemia alpha dan beta tidak kurang dari 2,4 per 1000 kelahiran. Anemia sel sickle menempati urutan teratas untuk kelainan pada hemoglobin. Thalassemia beta major dan HbE-thalassemia beta hampir sama banyaknya. Di Asia Tenggara dengan total penduduk lebih dari 600 juta, kelainan pada hemoglobin termasuk thalassemia, $\mathrm{HbE}$ dan $\mathrm{HbCS}$ merupakan kelainan genetik yang paling banyak ditemukan dan memiliki prevalensi tinggi. Indonesia memiliki beberapa daerah yang endemik malaria, sehingga diperkirakan banyak ditemukan kasus kelainan pada $\mathrm{Hb}$ termasuk thalassemia. Apabila presentase pembawa sifat thalassemia dikaitkan dengan angka kelahiran dan jumlah penduduk Indonesia, serta berdasarkan penelitian, maka diperkirakan jumlah penderita thalassemia baru yang lahir tiap tahunnya sekitar 2500 anak. Oleh karena kasus thalassemia makin meningkat dari tahun ke tahun, maka diperlukan upaya pencegahan yang dapat dimulai dengan skrining pada individu-individu yang memiliki kerabat pembawa atau penderita thalassemia.
\end{abstract}

Kata kunci: hemoglobinopati, thalassemia

\section{Abnormalities in Haemoglobin Synthesis: Thalassemia and It's Epidemiology}

\begin{abstract}
Hemoglobinopathy includes structural abnormalities and haemoglobin synthesis disorders (thalassemia), is a single gene disorder that was originally found in malaria endemic areas but nowadays can be found all over the world. The birth rate of homozygous or compound heterozygous hemoglobinopathies, including alpha and beta thalassemia is less than 2.4 per 1000 births. Sickle cell anemia is the most prevalent compared to beta major and HbE-beta thalassemia. In Southeast Asia with more than 600 million people, abnormalities in hemoglobin including thalassaemia, $\mathrm{HbE}$ and $\mathrm{HbCS}$ are the most common and highly prevalent genetic disorders. Indonesia, has several areas that are endemic to malaria, there are many cases of abnormalities in $\mathrm{Hb}$ including thalassemia. If the percentage of carriers is associated with the birth rate and the number of Indonesian population and based on the study, it is estimated that the number of thalassemia patients born each year around 2500 children. As the case of thalassemia is increasing from year to year, it is necessary that prevention starts with screening in individuals who have relatives known as a carrier or thalassemia patient.
\end{abstract}

Keywords: hemoglobinopathy, thalassemia

\section{PENDAHULUAN}

Hemoglobinopati atau kelainan pada Hemoglobin ( $\mathrm{Hb})$, mencakup semua kelainan genetik pada $\mathrm{Hb}$. Dua kelompok utama yang termasuk di dalamnya adalah perubahan struktur $\mathrm{Hb}$ yang menyebabkan varian $\mathrm{Hb}$ (varian utama adalah $\mathrm{HbS}, \mathrm{HbC}$ dan $\mathrm{HbE}$ ) serta gangguan sintesis $\mathrm{Hb}$ yang dengan satu atau lebih rantai globin tersupresi secara total atau 
parsial dan menyebabkan suatu kelainan yang disebut thalassemia. Bentuk yang lebih jarang adalah kombinasi kedua kelainan tersebut (1). Sejauh ini, kelainan pada $\mathrm{Hb}$ menjadi kelainan gen tunggal yang paling banyak ditemukan di dunia. Awalnya, kelainan ini terutama ditemukan di daerah endemis malaria, yaitu di Mediterania dan sebagian besar Asia dan Afrika. Salah satu alasannya adalah karena individu carrier atau pembawa hemoglobinopati lebih tahan terhadap serangan malaria. Keuntungan ini menyebabkan adanya seleksi terhadap penduduk yang tinggal di daerah endemis malaria di daerah tropik dan sub tropik sehingga terjadi peningkatan frekuensi gen penyebab hemoglobinopati di daerah-daerah tersebut (2).Saat ini hemoglobinopati dapat ditemukan di bagian dunia mana pun termasuk di daerah industri yang non-endemik malaria karena terjadi migrasi penduduk dari daerah endemik malaria dalam rangka mencari pekerjaan atau penghidupan yang lebih baik (2).

Hemoglobinopati menyebabkan masalah kesehatan yang signifikan pada 71\% dari 229 negara-negara, termasuk kelahiran bayi-bayi di seluruh dunia. Lebih dari 330.000 bayi lahir tiap tahunnya dengan hemoglobinopati (83\% penyakit sel sickle, $17 \%$ thalasemia). Kelainan $\mathrm{Hb}$ menyebabkan 3,4\% kematian anak-anak di bawah 5 tahun. Secara global, setidaknya 5,2\% populasi dunia dan sekitar $7 \%$ wanita hamil membawa kelainan pada $\mathrm{Hb}$, dan lebih dari $1 \%$ merupakan pasangan beresiko untuk memiliki anak dengan kelainan pada $\mathrm{Hb}$ (3). Sekitar 4,83\% populasi dunia merupakan pembawa rantai globin varian, termasuk $1,67 \%$ dari populasi merupakan individu heterosigot thalassemia alpha dan thalassemia beta. Pembawa $\mathrm{HbE}$ sebanyak 0,95\% dan pembawa $\mathrm{HbC}$ sebesar 0,29\%, sehingga di seluruh dunia, tingkat kelahiran individu homosigot atau compound heterozygote kelainan pada hemoglobin, termasuk thalassemia alpha dan beta tidak kurang dari 2,4 per 1000 kelahiran, dengan 1,96 menderita penyakit anemia sel sickle dan sisanya sebesar 0,44 menderita thalassemia (4). Riset oleh Christianson, et al (2006) menunjukkan tiap tahun sebanyak 30.000 sampai 40.000 bayi lahir dengan kelainan serius pada hemoglobinnya (5). Anemia sel sickle menempati urutan teratas untuk kelainan pada hemoglobin. Setidaknya 180 ribu bayi lahir tiap tahunnya di sub-Sahara
Afrika dengan kondisi ini, sedangkan pada thalassemia, kasus thalassemia beta major dan $\mathrm{HbE}$-thalassemia beta hampir sama banyaknya. Hemoglobin E (HbE)-thalassemia beta dapat ditemukan dengan frekuensi tinggi pada anak benua (subcontinent) India, Bangladesh, Myanmar dan sepanjang Asia Tenggara, sedangkan kasus thalassemia alpha yang parah hanya terbatas pada Asia Tengggara. Meskipun demikian, data-data di atas hanya berdasarkan survei yang didapat dari sejumlah kecil pusat-pusat analisa pada tiap-tiap negara, sehingga dibutuhkan pemetaan mikro (micromapping) lebih lanjut terutama pada negara-negara dengan kelainan pada $\mathrm{Hb}$ ditemukan dengan frekuensi tinggi (6).

Dengan total penduduk lebih dari 600 juta dan sangat heterogen, kelainan pada hemoglobin, termasuk di dalamnya thalassemia, $\mathrm{HbE}$ dan $\mathrm{Hb}$ Constant Spring ( $\mathrm{HbCS}$ ) merupakan kelainan genetik yang paling banyak ditemukan dan memiliki prevalensi tinggi di Asia Tenggara (7). Indonesia adalah salah satu negara di Asia Tenggara yang beriklim tropis dan beberapa daerah merupakan endemik malaria, sehingga diperkirakan banyak ditemukan kasus kelainan pada $\mathrm{Hb}$ termasuk thalassemia. Untuk itu perlu diketahui bagaimana perkembangan epidemiologi thalassemia pada beberapa negara di dunia dan khususnya di berbagai daerah di Indonesia.

\section{PEMBAHASAN}

\section{Stuktur Hemoglobin}

Hemoglobin adalah molekul protein tetramerik terdiri dari protoporphyrin dan besi, yang ditemukan di eritrosit (sel darah merah) semua vertebrata. Protein hemoglobin A berbentuk globuler, terdiri dari dua rantai $\alpha$ globin dan 2 rantai $\beta$ globin. Molekul $\alpha 2 \beta 2$ inilah yang menyusun hemoglobin individu dewasa. Tiap-tiap sub unit (alpha dan beta) mengandung grup heme, dengan satu atom besi untuk melekatnya oksigen atau ligand yang lain secara reversibel. Hemoglobin berperan dalam proses respiratori, yaitu sebagai transport oksigen $\left(\mathrm{O}_{2}\right)$ dari paru-paru ke jaringan-jaringan tubuh dan membawa kembali karbondioksida. Hemoglobin juga berinteraksi dengan gas lain, yaitu karbon monoksida (CO) dan nitric oksida (NO), yang memiliki peran biologis (8). 
ISSN 1978-2071 (Print); ISSN 2580-5967 (Online) Jurnal IImiah Kedokteran Wijaya Kusuma 5(2) : 33-43

Pada orang dewasa yang sehat, 95\% Hemoglobin adalah $\mathrm{HbA}(\alpha 2 \beta 2)$ dengan sejumlah kecil (3,5\%) merupakan $\mathrm{HbA} 2$ $(\alpha 2 \delta 2)$ dan $\mathrm{HbF}(\alpha 2 \gamma 2)$. Pada sel diploid terdapat empat gen $\alpha$ dan dua gen $\beta$ atau $\beta$-like $(\delta, \gamma)$. Rantai $\alpha$ dan $\beta$ terdiri dari 141 dan 146 asam amino. Meskipun demikian, terdapat kesamaan sekuen di antara ke dua rantai tersebut (64 asam amino pada posisi yang identik), dan rantai $\beta$ berbeda dari rantai $\delta, \gamma$ pada 39 dan 10 asam aminonya (9).

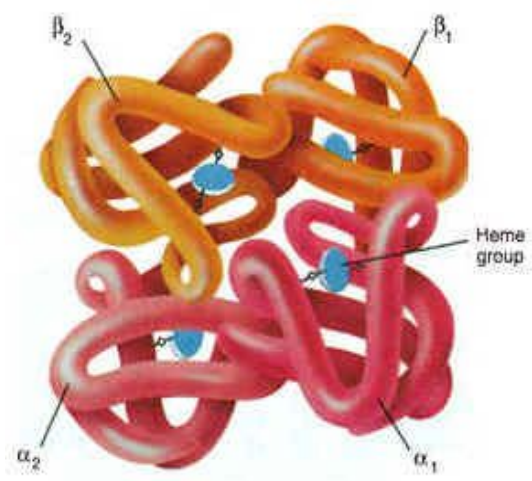

Gambar 1. Molekul hemoglobin (Hb)A. Hemoglobin A terdiri dari dua rantai alphadan dua rantai beta ( $\alpha 2 \beta 2$ ), dengan struktur besi tempat melekatnya oksigen (10).

Sintesis setiap globin dikontrol oleh gen-gen berbeda, yang diatur dalam dua kelompok: gen yang mengkode rantai $\alpha$ dan $\zeta$ (kelompok $\alpha$ ) yang berlokasi pada regio telomer lengan pendek kromosom 16 (16p13.3), sementara gen-gen yang mengkode rantai $\beta, \delta, \gamma$ dan $\varepsilon$ (kelompok $\beta$ ) terletak pada lengan pendek kromosom 11 (11p15.5). Enam bulan setelah lahir, $\mathrm{HbA}$ dominan, menyusun $95 \%$ total $\mathrm{Hb}$ seluler, sementara level $\mathrm{HbA} 2$ sekitar 2-3\% dan level $\mathrm{HbF}$ adalah $0-2 \%$ (11).

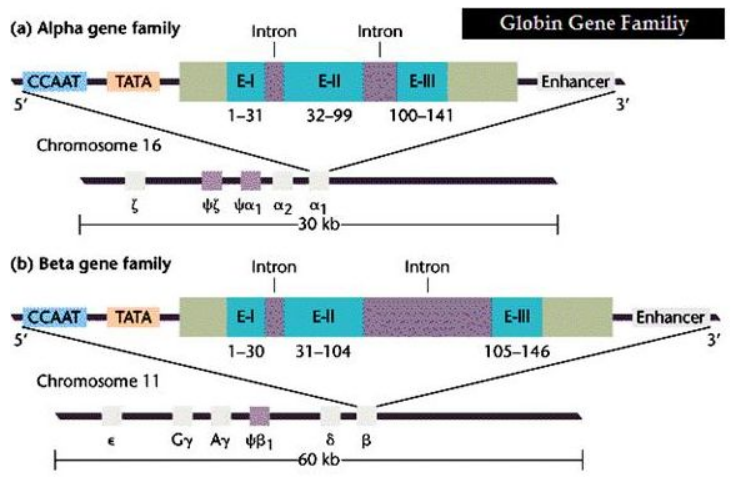

Gambar 2. Gen globin $\alpha$ dan $\alpha$-like pada kromosom 16 (atas) dan gen globin $\beta$ dan $\beta$-like pada kromosom 11 (bawah)(12).

\section{Switching Hemoglobin pada Manusia}

Produksi $\mathrm{Hb}$ pada manusia dikarakterisasi oleh dua pergantian utama: produksi $\mathrm{Hb}$ embryonik, yaitu $\mathrm{Hb}$ Gower 1 ( $\zeta 2 \varepsilon 2$ ); Hb Gower 2 $(\alpha 2 \varepsilon 2)$ dan $\mathrm{Hb}$ Portland $(\xi 2 \gamma 2)$ dan perubahan setelah 2 bulan masa kehamilan dengan diproduksinya dua jenis $\mathrm{Hb}$ janin (fetal) ( $\alpha 2 \mathrm{G} \gamma 2$ dan $\alpha 2 \mathrm{~A} \gamma 2$ ) dan sesaat sebelum lahir menjadi $\mathrm{HbA}(\alpha 2 \beta 2)$ (13).

Hemoglobin fetal (HbF) adalah komponen $\mathrm{Hb}$ selama kehidupan janin dan saat lahir, merupakan $80 \%$ hemoglobin total pada bayi baru lahir. Hemoglobin fetal (HbF) diproduksi pada minggu ke enam kehamilan dan selama kehidupan janin, menggantikan $\mathrm{Hb}$ embryo (Gower I, Gower II dan Portland). Setelah bayi lahir, sintesis $\mathrm{HbF}$ menurun dengan cepat dan secara bertahap $\mathrm{HbF}$ digantikan oleh $\mathrm{HbA}$ pada darah perifer, sehingga dalam dua tahun pertama kehidupan, fenotip $\mathrm{Hb}$ telah sama dengan fenotip $\mathrm{Hb}$ pada dewasa dengan level $\mathrm{HbF}$ sangat rendah (kurang dari 1\%). Pada dewasa normal, HbF didistribusikan di antara sel darah merah walaupun sintesisnya terbatas pada populasi sel-sel yang disebut sel F. Sekitar 3-7\% sel darah merah adalah sel-F, yang mengandung $20-25 \% \mathrm{HbF}$. Hemoglobin fetal dibentuk dari dua rantai globin $\alpha$ dan dua rantai globin $\gamma(\alpha 2 \gamma 2)$, yang terdiri dari 141 dan 146 residu asam amino. Rantai $\gamma$ merupakan karakteristik dari $\mathrm{HbF}$ dan berbeda dari rantai $\beta$ yang lain pada 39 residu. Terdapat dua macam rantai- $\gamma$ yang terdapat pada $\mathrm{HbF}$, yaitu $\mathrm{G} \gamma$ dan $A \gamma$, yang ke duanya berfungsi secara identik tetapi berbeda pada asam amino ke-136 yang mungkin alanin atau glycine. Rantai globin $\mathrm{G} \gamma$ dan $A \gamma$ dikode oleh dua gen berbeda yang berlokasi pada kluster globin $\beta$ pada kromosom nomer 11. Rasio Gy dan Ay sekitar 70:30 saat lahir dan umumnya 40:60 pada $\mathrm{HbF}$ yang ditemukan pada individu dewasa. Perubahan rasio ini dapat ditemukan pada beberapa kelainan pada hemoglobin (14). 
ISSN 1978-2071 (Print); ISSN 2580-5967 (Online)

Jurnal IImiah Kedokteran Wijaya Kusuma 5(2) : 33-43

A.

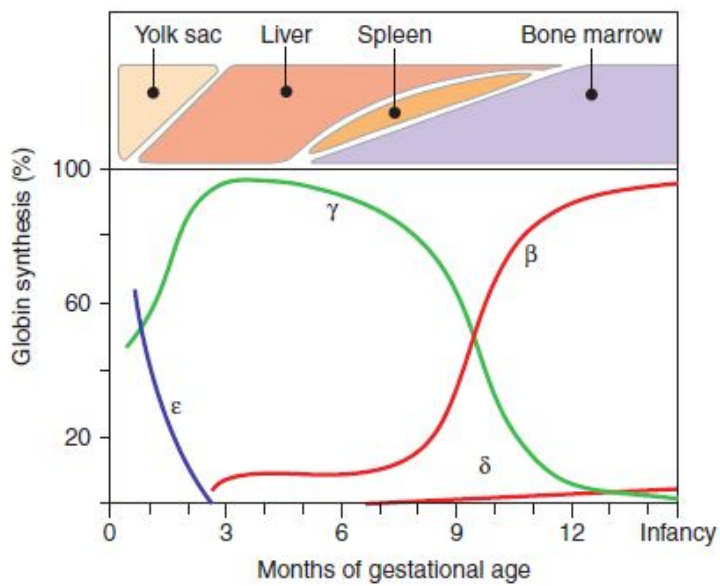

$\beta$-Globin locus

B.

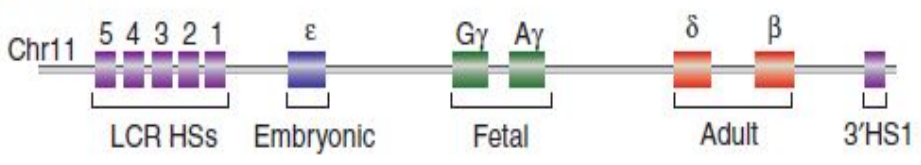

Gambar 3. Sintesis rantai globin (dalam persentase) dan organ yang memproduksi pada tahapan usia kehamilan (dalam bulan)(15).

Keterangan :

A. Tempat dan level berbagai molekul $\beta$-like globin dengan warna sesuai dengan bermacam gen pada lokus globin beta (pada gambar B). (embryonik berwarna biru, fetal dalam warna hijau dan $\mathrm{Hb}$ dewasa berwarna merah).

B. Gambar menunjukkan enhancer pada upstream dari lokus globin beta, yang dikenal sebagai locus control region (LCR), HS1 adalah singkatan dari DNAse I hypersensitivity sites.

\section{Kelainan pada Hemoglobin (Hemoglobinopati) Definisi}

Hemoglobinopati merupakan hasil mutasi yang mempengaruhi gen-gen globin dan dapat diklasifikasikan menjadi dua kelompok utama: perubahan struktural yang membentuk suatu anomali, $\mathrm{Hb}$ varian, dan perubahan sintesis $\mathrm{Hb}$ yang menyebabkan thalassemia, dengan satu atau lebih tipe rantai globin tersupresi secara parsial atau total; atau dapat pula terjadi kombinasi kedua fenotip (11),

Kelainan keturunan pada hemoglobin ini dapat dikelompokkan menjadi 6 kelompok besar, yaitu:(16)

1. Varian pada struktur $\mathrm{Hb}$, seperti (HbS dan $\mathrm{HbC}$ ), yang disebabkan perubahan satu asam amino (mutasi misense)
2. Thalassemia, dengan karakterisasi berkurangnya sintesis satu atau lebih rantai globin pada hemoglobin.

3. Sintesis hemoglobin fetal ( $\left.\begin{array}{lll}H b & \text { F }\end{array}\right)$ tetap bertahan di luar periode neonatal yang kesemuanya dikenal sebagai hereditary persistence of fetal hemoglobin (HPFH)

4. Hemoglobin yang tidak stabil

5. Varian $\mathrm{Hb}$ dengan afinitas oksigen yang berubah

6. Methemoglobin ( $\mathrm{Hb} \mathrm{M})$

\section{Hemoglobin Varian}

Lebih dari 300 struktur varian hemoglobin telah diketahui, sebagian besar disebabkan substitusi satu asam amino. Istilah 'varian' digunakan daripada 'abnormal' karena tidak berkaitan dengan penyakit. Hemoglobin yang abnormal dapat diklasifikasikan berdasarkan jenis mutasi yang mendasari atau konsekuensi klinis yang diakibatkannya. Kondisi heterosigot disebut pembawa, sedang pada keadaan homosigot menyebabkan kelainan. 
ISSN 1978-2071 (Print); ISSN 2580-5967 (Online)

Jurnal IImiah Kedokteran Wijaya Kusuma 5(2) : 33-43

Varian hemoglobin yang ada antara lain $\mathrm{HbS}$,

$\mathrm{HbD}$, Punjab, $\mathrm{HbE}, \mathrm{HbH}, \mathrm{HbM}, \mathrm{HbBart}, \mathrm{HbG}$

Philadelphia dan $\mathrm{HbHasheron} \mathrm{(17).}$

Tabel 1. Prevalensi pembawa gen hemoglobinopati di berbagai belahan dunia (1).

\begin{tabular}{ll}
\hline \multicolumn{1}{c}{ Regio } & \multicolumn{1}{c}{ Gene carriers } \\
\hline Afrika & $5-30 \%$ \\
Negara-negara Arab & $5-40 \%$ sampai dengan 60\% tergantung negaranya \\
Asia Tengah dan India & $10-20 \%$ \\
Asia Tenggara & $5-40 \%$ sampai dengan 70\% tergantung negaranya \\
USA dan Amerika Tengah & $5-20 \%$ \\
Itali & $7-9 \%$ \\
Yunani & $6-7 \%$ \\
Turki & $7-10 \%$ \\
Jerman & Di antara populasi keseluruhan: $0.5-1 \%$ \\
Inggris Raya & Di antara penduduk imigran: $5 \%$ \\
Portugal, & \\
Spanyol, & \\
Perancis, & \\
Belanda, & \\
Belgia, & \\
Negara-negara Skandinavia, & \\
Albania & \\
Yugoslavia, & \\
Kroasia, & \\
Bosnia-Herzegovina, & \\
Bulgaria, & \\
Rusia & \\
Transkaukasia & \\
\hline
\end{tabular}

\section{Kelainan Sintesis Hemoglobin : Thalassemia}

\section{Definisi}

Thalassemia, adalah kelainan yang ditandai dengan anemia pada penderitanya karena berkurangnya sintesis rantai globin pada hemoglobin. Thalassemia diklasifikasikan sesuai rantai molekul globin yang mengalami kelainan, alpha dan beta. Thalassemia alpha disebabkan delesi pada gen alpha globin, sedangkan thalassemia beta disebabkan adanya mutasi pada gen beta globin. Secara umum, tingkat keparahan thalassemia alpha berhubungan dengan jumlah gen alpha yang mengalami delesi. Individu dengan delesi 1 gen umumnya tidak menunjukkan gejala, delesi 2 gen alpha dapat terdeteksi pada pemeriksaan darah meskipun penderita tampak normal, delesi 1 gen pada salah satu alel dan alel yang lain terdapat delesi 2 gen alpha, disebut thalassemia intermedia, sedangkan delesi pada semua gen alpha globin menyebabkan alpha thalassemia major atau $\mathrm{Hb}$ Bart's hydrops fetalis, yang merupakan kelainan thalassemia yang paling parah dan bersifat lethal (7).

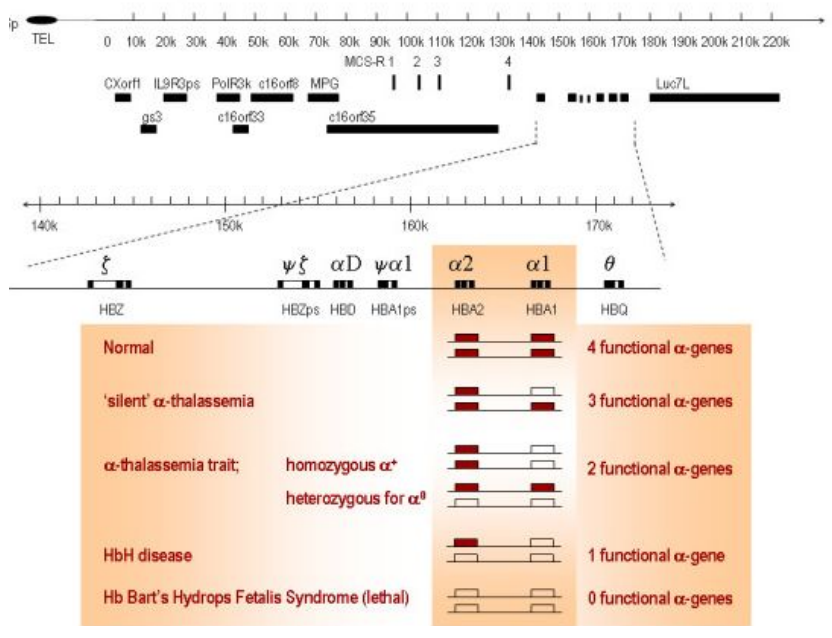


Gambar 4. Delesi gen pada thalassemia alpha (18). Pada individu normal terdapat 4 gen alpha globin. Delesi 1 gen alpha disebut silent thalassemia, delesi 2 gen beta disebut

Pada thalassemia beta terdapat tiga macam kategori : 1). thalassemia major, seringkali disebut sebagai anemia Cooley (Cooley's anemia) atau anemia mediterania (Mediterranean anemia), umumnya memiliki genotip homosigot atau compound heterozygote beta ${ }^{0}$ atau beta ${ }^{+} ; 2$ ). thalassemia intermedia dengan genotip homosigot atau compound heterozygote dan 3) thalassemia minor, disebut juga pembawa thalassemia beta (beta-thalassemia carrier), pembawa sifat thalassemia beta (beta-thalassemia trait) atau thalassemia beta heterosigot (heterozygous beta-thalassemia), umumnya memiliki genotip heterosigot (19).

Thalassemia beta homosigot bersifat parah. Anak-anak dengan thalassemia major tampak sehat saat lahir karena $\mathrm{HbF}$ masih berfungsi. Patologi muncul saat $\mathrm{HbA}$ menggantikan $\mathrm{HbF}$. Kerusakan pada gen beta mengakibatkan ketidakseimbangan sintesis rantai globin yang menyebabkan pengurangan $\mathrm{Hb}$ pada sel darah merah. Eritropoiesis tidak efektif dan usia sel darah merah memendek, sehingga penderita mengalami anemia. Kegagalan jantung karena anemia dan infeksi dapat menyebabkan kematian pada anak-anak yang menderita thalassemia tetapi tidak mendapatkan terapi (7).

\section{Epidemiologi Thalassemia}

Thalassemia merupakan kelainan pada gen tunggal yang paling umum ditemukan. Penyebaran penyakit ini mulai dari Mediterania, Timur Tengah, anak benua (subcontinent) India dan Burma, sepanjang garis antara Cina bagian Selatan, Thailand, semenanjung Malaysia, Kepulauan Pasifik dan Indonesia (20). Hasil daripenelitian epidemiologi menunjukkan individu pembawa gen thalassemia alpha atau beta dapat bertahan terhadap serangan malaria falciparum pada daerah-derah yang endemik. Perkawinan antar kerabat juga memberikan kontribusi tingginya prevalensi thalassemia pada daerah-derah tersebut (6). Akan tetapi, karena adanya migrasi penduduk dari daerah dengan prevalensi tinggi, maka kelainan ini dapat ditemukan di seluruh dunia (21). thalassemia alpha trait, delesi 3 gen disebut $\mathrm{HbH}$ disease, sedangkan delesi 4 gen alpha disebut $\mathrm{Hb}$ Bart's hydrops fetalis.

Diperkirakan, jumlah individu pembawa lebih dari 270 juta, dan lebih dari 300,000 anak-anak dengan thalassemia atau salah satu varian struktur hemoglobin lahir tiap tahun (21).Tabel 2 menggambarkan kelainan hemoglobinopati dan jumlah penderita yang lahir tiap tahunnya.

Tabel 2. Jumlah kelahiran bayi dengan kelainan hemoglobin per tahun (6).

\begin{tabular}{lr}
$\begin{array}{l}\text { Kelahiran bayi dengan berbagai } \\
\text { hemoglobin major per tahun }\end{array}$ & \\
\hline Thalassemia beta major & 2.989 \\
HbE-thalassemia beta & 19.218 \\
HbH disease & 9.568 \\
Hb Bart's hydrops $\left(\alpha^{\circ} / \alpha^{\circ}\right)$ & \\
5.183 & \\
SS disease & 217.331 \\
S-thalassemia beta & 11.074 \\
Sickle cell disease & 54.736 \\
\hline
\end{tabular}

Pada Tabel 2 terlihat anemia sel sickle menempati urutan tertinggi kelainan hemoglobin pada bayi yang lahir di seluruh dunia, diikuti thalassemia beta major dan $\mathrm{HbE}$-thalassemia beta. Meskipun demikian, data di atas mungkin tidak akurat, sehingga dibutuhkan pemetaan mikro (micromapping) lebih lanjut terutama pada negara-negara dengan frekuensi kelainan hemoglobin yang tinggi (6).

Diperkirakan, sekitar $1.5 \%$ dari populasi dunia atau 80 sampai 90 juta penduduk adalah pembawa thalassemia beta, sebagian besar berada di negara yang sedang berkembang. Insidensi individu yang menunjukkan gejala thalassemia adalah $1: 100.000$ penduduk per tahun di seluruh dunia dan 1 : 10.000 orang di negara-negara Uni Eropa. Akan tetapi, pada negara-negara yang diketahui atau diperkirakan banyak penduduknya menderita thalassemia, data akurat jumlah individu pembawa (carrier) tidak tersedia. Menurut Thalassemia International Federation, hanya sekitar 200.000 penderita thalassemia major yang bertahan hidup dan tercatat menerima pengobatan teratur di seluruh dunia. Kombinasi yang paling umum ditemukan adalah thalassemia beta dengan $\mathrm{Hb}$ abnormal atau varian struktur $\mathrm{Hb}$, yaitu $\mathrm{HbE} /$ thalassemia beta dan paling banyak 
ditemukan di Asia Tenggara, dengan frekuensi carrier sekitar 50\% (19).

\section{Epidemiologi di Amerika}

Diperkirakan 1 : 55000 bayi lahir menderita thalassemia di California, tetapi sejak adanya implementasi skrining bayi baru lahir untuk hemoglobinopati (selain sel sickle) yang dimulai tahun 1990, tingkat kelahiran bayi dengan thalassemia major dan $\mathrm{HbE}$-thalassemia beta di California menunjukkan angka yang stabil pada $1,6 / 100.000$. Thalassemia alpha juga banyak ditemukan pada bayi baru lahir dengan perkiraan 1/9000 kelahiran (22).

\section{Epidemiologi diberbagai negara di Eropa}

Analisa Hemoglobin untuk deteksi dan identifikasi varian hemoglobin dan sindroma thalassemia di Jerman dilakukan pertama kali pada tahun 1959 oleh Betke dan Kleihauer. Dari 100.000 orang yang diidentifikasi, ditemukan lebih dari 30.000 (34\%) penderita. Dari jumlah ini, sindroma thalassemia menempati urutan teratas dengan 25.798 kasus atau $25.6 \%$, diikuti oleh kelainan struktur $\mathrm{Hb}$ (8.430 kasus atau $8.4 \%)$. Hal ini menunjukkan bahwa kelainan hemoglobin memiliki relevansi praktek klinik pada populasi di Jerman yang memiliki banyak imigran. Dari hasil penelitian, ada kemungkinan 400.000 penduduk Jerman merupakan pembawa gen hemoglobinopati (23).

Di Belanda, laporan mengenai prevalensi hemoglobinopati yang rendah menyebabkan pemerintah tidak melakukan tindakan preventif, sampai kemudian adanya serial publikasi yang bertolak belakang dari laporan sebelumnya yang dilakukan sejak tahun 2003 menunjukkan tiap tahun diperkirakan terdapat 800 penderita dengan anemia sel sickle dan thalassemia beta dan 60 bayi lahir dengan hemoglobinopati (1 di antara 3000 kelahiran) (24).

Berdasarkan hasil skrining, 0,63\% dari semua kelahiran di Belanda adalah pembawa salah satu dari $\mathrm{Hb}$ variant yang utama ( $\mathrm{HbS}$, $\mathrm{HbC}$, HbD-Los Angeles atau $\mathrm{HbE}$ ) yang berhubungan dengan penyakit yang serius. Artinya, sekitar 1200 individu pembawa hemoglobinopati lahir tiap tahun, dan lebih dari 700 pembawa gen sickle. Lebih jauh lagi, 40-50 bayi lahir merupakan penderita sickle cell disease atau tahalassemia beta (24).

Tabel 3. Frekuensi alel pembawa gen thalassemia pada berbagai area di dunia dalam persentase (25).

\begin{tabular}{lccc}
\hline Region & $\beta$-thalassemia & $\alpha^{0}$-thalassemia \\
$\alpha^{+}$-thalassemia & \multicolumn{3}{l}{} \\
\hline Americas & 0.3 & $0-5$ & $0-40$ \\
Eastern Mediteranian & $2-18$ & $0-2$ & $1-60$ \\
Europe & $0-19$ & $1-2$ & $6-12$ \\
Southeast Asia & $0-11$ & $1-30$ & $8-40$ \\
Sub-Saharan Africa & $0-12$ & 0 & $10-50$ \\
Western Pacific & $0-13$ & 0 & $2-60$ \\
\hline
\end{tabular}

\section{Epidemiologi di negara-negara Afrika dan Asia}

Thalassemia terdapat pada area yang mencakup geografis yang luas termasuk Mediterania, Timur Tengah, India dan Asia Tenggara tetapi muncul sporadik pada populasi-populasi lainnya. Thalassemia $\alpha^{0}$ pada umumnya banyak ditemukan di Mediterania dan Oriental, tetapi sangat jarang di Afrika dan Timur Tengah.Studi awal di Afrika Barat menunjukkan frekuensi pembawa thalassemia beta sekitar 9\% di Liberia dan angka yang sama telah dilaporkan dari Ghana dan Pantai Gading. Hal ini menunjukkan hal yang sangat kontras dengan laporan sebelumnya yang menyebutkan prevalensi di Nigeria hanya $0.8 \%$, walaupun negara-negara tersebut memiliki iklim yang sama (26).Di Pakistan, thalassemia beta merupakan salah satu kelainan genetik yang umum ditemukan dengan prevalensi pembawa pada regio-regio berbeda bervariasi antara $1.4-8 \%$ dengan angka rata-rata 5\% (27). 
ISSN 1978-2071 (Print); ISSN 2580-5967 (Online)

Jurnal IImiah Kedokteran Wijaya Kusuma 5(2) : 33-43

Tabel 4. Persentase pembawa gen thalassemia dan hemoglobin varian (7;27-29).

\begin{tabular}{lcccc}
\hline \multicolumn{1}{c}{ Country } & $\boldsymbol{\alpha}$ & \% Carriers & \\
& ND & $\beta$ & Hb E & Hb CS \\
\hline Bangladesh & $(+)$ & $(+)$ & 4 & $(-)$ \\
Cambodia & 15 & 5 & $(+)$ & $(-)$ \\
China : Guang xi & 22 & $3-6$ & $(-)$ & $(-)$ \\
China : Hong Kong & 4 & $1-3$ & $(-)$ & $(-)$ \\
China : Taiwan & $5-97$ & $3-4$ & $(+)$ & $(+)$ \\
India & $6-16$ & $3-10$ & $1-25$ & $(-)$ \\
Indonesia & $(+)$ & $(+)$ & $(+)$ & \\
Laos & 4.5 & 4.5 & $(+)$ & $(+)$ \\
Malaysia & 28 & 18 & 0.69 & 0.4 \\
Maldives & 10 & $0.5-1.5$ & $2-2.8$ & $(-)$ \\
Myanmar & $(-)$ & 5 & $(-)$ & $(-)$ \\
Pakistan & 5 & 1.9 & $(-)$ & $(-)$ \\
Philipina & 2.92 & 0.93 & 0.64 & $(-)$ \\
Singapore & $(+)$ & 2.2 & 0.5 & $(-)$ \\
Sri Lanka & $10-30$ & $3-9$ & $10-53$ & $(-)$ \\
Thailand & 2.5 & 1.5 & $(+)$ & $(-)$ \\
Vietnam & & & &
\end{tabular}

Keterangan: ND (not determined); (+): ditemukan kasus tetapi tidak diketahui persentasenya; (-) : tidak ditemukan kasus atau tidak diketahui karena belum dilakukan penelitian.

\section{Epidemiologi di negara-negara Asia Tenggara}

Di negara-negara Asia Tenggara, thalassemia alpha, thalassemia beta, $\mathrm{Hb}$ E dan $\mathrm{HbCS}$ banyak ditemukan. Frekuensi gen thalassemia alpha dapat mencapai $30-40 \%$ di Thailand Utara dan Laos, 4,5\% di Malaysia dan $5 \%$ di pulau-pulau terpencil di Philipina, sementara, frekuensi gen untuk thalassemia beta bervariasi antara 1-9\% (7). Menurut Greenberg (2001), 1\% dari 60 juta penduduk di Thailand, menderita thalassemia dan lebih dari 20 juta merupakan pembawa thalassemia (30). Di Malaysia, thalassemia beta telah berkembang sebagai salah satu problema kesehatan masyarakat pada penduduk Malaysia yang multirasial, khususnya diantara penduduk China Malaysia dan Malay, dimana pembawa sifat thalassemia beta berkisar 4,5\% (29).

Penelitian mengenai thalassemia alpha di Indonesia diawali oleh Lie Injo (1959) yang menemukan frekuensi thalassemia alpha sebesar $0.4 \%$ dan pada tahun 1960 kasus $\mathrm{Hb}$
Bart's hydrops fetalis pertama kali ditemukan.Penelitian terhadap 103 individu sehat di Maumere, Flores, oleh Sofro (1993)menunjukkan angka pembawa gen thalassemia beta sebesar $6 \%$ dan hanya 1 individu pembawa $\mathrm{HbE}$ (31).sedangkan di Makasar dari 103 sampel didapatkan 8 sampel (13\%) merupakan pembawa thalassemia beta (32). Dari penelitian terhadap 92 individu di Maluku, didapatkan 6 individu (6.5\%) merupakan pembawa thalassemia beta (33).Penelitian oleh Setianingsih et al. (1998) pada kelompok etnik yang berbeda di Indonesia, ditemukan 13 macam mutasi, dan mutasi terbanyak yang ditemukan adalah $\mathrm{HbE}$ (29\%). Hasil penelitian juga melaporkan adanya penderita yang berasal dari Indonesia bagian Timur dengan HbLepore dan Filipino $\beta$-deletion(34). Pada tahun 1999, dilaporkan adanya penderita thalassemia dengan genotip compound heterozygoteFilipino $\beta^{\circ}$-thalassemia/HbE (35). 
Tabel 5. Persentase pembawa thalassemia $\alpha$, thalassemia $\beta$ dan $\mathrm{Hb}$ E pada beberapa daerah di Indonesia (31-33;36)

\begin{tabular}{|c|c|c|c|}
\hline \multirow[t]{2}{*}{ Daerah } & \multicolumn{3}{|c|}{ Carrier (\%) } \\
\hline & $\begin{array}{c}\text { Thalasse } \\
\text { mia } \alpha\end{array}$ & $\begin{array}{c}\text { Thalasse } \\
\text { mia } \beta\end{array}$ & $\mathrm{Hb} \mathrm{E}$ \\
\hline $\begin{array}{l}\text { Maumere, } \\
\text { Flores }\end{array}$ & $(-)$ & 6 & $(-)$ \\
\hline Makasar & $(-)$ & 13 & $(-)$ \\
\hline Maluku & 15 & 6.5 & $(-)$ \\
\hline Medan & 3.35 & 4.07 & 0.26 \\
\hline Surabaya & 2.2 & 4 & 6.2 \\
\hline
\end{tabular}

Penelitian molekuler thalassemia alpha dilakukan sekitar dua dekade yang lalu pada 103 sampel yang berasal dari populasi Jawa, hasilnya menunjukkan 3\% penduduk menderita $\alpha^{+}$-thalassemia (37). Di Indonesia, angka pembawa sifat thalassemia beta adalah $3-5 \%$, dan di beberapa daerah tertentu mencapai $10 \%$ (38). Diberbagai daerah di Indonesia angka ini dapat berbeda-beda. Sebagai contoh, di
Medan, dari 1521 sampel darah yang berasal dari individu sehat, ditemukan presentase pembawa gen thalassemia alpha sebesar $3,35 \%$, thalassemia beta $(4,07 \%)$ dan $\mathrm{HbE}$ $(0,26 \%)$ (39).

Minimnya penelitian pada thalassemia alpha disebabkan sebagian besar penderita thalassemia yang dirawat di rumah sakit adalah thalassemia beta. Meskipun demikian, penelitian oleh Setianingsih et al (2003) pada 1470 individu dengan menggunakan parameter hematologi menunjukkan frekuensi $\alpha^{+}$-thalassemia pada populasi Jawa sebesar $2,7 \%$, Sumatera Selatan sebesar $10 \%$ dan di Sulawesi Selatan sebesar 11\%, sedangkan frekuensi $\alpha^{0}$-thalassemia pada tiga tempat tersebut antara 2,6\%-3,2\% (40).

Penelitian thalassemia di Jakarta dengan menggunakan amplifikasi PCR dan sekuensing DNA, menunjukkan kasus thalassemia alpha sebesar $32 \%$ seperti ditunjukkan pada tabel 6 (40).

Tabel 6. Persentase penderita thalassemia alpha dan beta berdasarkan etnis di Jakarta (40).

\begin{tabular}{lcccc}
\hline & \multicolumn{3}{c}{ Thalassemia beta } & \multicolumn{2}{c}{ Thalassemia } \\
alpha & $\mathrm{N}$ & $\%$ & $\mathrm{~N}$ & $\%$ \\
\hline Total & 67 & 68 & 32 & 32 \\
Jawa & 45 & 67 & 10 & 31 \\
China & 22 & 33 & 22 & 69 \\
\hline
\end{tabular}

Dari tabel di atas, jelas terlihat bahwa kasus thalassemia alpha lebih banyak ditemukan pada etnis Cina dibanding Jawa, dan sebaliknya kasus thalassemia beta lebih banyak ditemukan pada etnis Jawa dibanding Cina.

Di Indonesia, apabila presentase pembawa sifat thalassemia dikaitkan dengan angka kelahiran dan jumlah penduduk Indonesia serta berdasarkan penelitian, maka diperkirakan jumlah penderita thalassemia baru yang lahir tiap tahunnya sekitar 2500 anak (41). Oleh karena kasus thalassemia makin meningkat dari tahun ke tahun, maka diperlukan upaya pencegahan yang dapat dimulai dengan pemeriksaan darah pada individu-individu yang memiliki kerabat yang diketahui merupakan pembawa atau penderita thalassemia. Untuk itu dibutuhkan penelitian molekuler dengan metode yang praktis, mudah dan murah, untuk mengetahui berbagai macam mutasi penyebab thalassemia di Indonesia. Salah satu metode yang dapat digunakan adalah Multiplex ARMS-PCR (Amplification Refractory Mutation System-Polymerase Chain Reaction) atau PCR-RFLP (Restriction Fragment Length Polymorphism).

\section{DAFTAR PUSTAKA}

1. Kohne E, 2011. Hemoglobinopathies Clinical Manifestations, Diagnosis, and Treatment. Deutsches Arzteblatt, 108: 532-540.

2. Amato A and Giordano PC, 2009. Screening and Genetic Diagnosis of Hemoglobinopathies in Southern and Northern Europe: Two Examples. Mediterranean Journal of Hematology and Infectious Diseases, 1.

3. Modell B and Darlison M, 2008. Global epidemiology of haemoglobin disorder and 
derived service indicators. Public health reviews, 86: 480-487.

4. Angastiniotis $M$, and Modell B, 1998. Global epidemiology of hemoglobin disorders. Ann NY Acad Sci, 850: 251-69.

5. Williams TN, and Weatherall DJ, 2012. World Distribution, Population Genetics, and Health Burden of the Hemoglobinopathies. Cold Spring Harbor Perspective in Medicine.

6. Weatherall DJ, 2010. The inherited diseases of hemoglobin are an emerging global health burden Blood, 115: 4331-4336.

7. Fucharoen S and Winichagoon P, 2011. Haemoglobinopathies in Southeast Asia. Indian Journal Medical Res, 498-506.

8. Schechter AN, 2008. Hemoglobin research and the origins of molecular medicine. Blood 112: 3927-3938.

9. Clarke GM, and Higgins TN, 2000. Laboratory Investigation of Hemoglobinopathies and Thalassemias: Review and Update Clinical Chemistry, 46: 1284-1290.

10. Anonymous. Blood. Diunduh dari https://basicmedicalkey.com/blood/

11. Sonati MF, and Costa FF, 2008. The genetics of blood disorders: the hereditary hemoglobinopathies. Jornal de Pediatria, 84.

12. Anonymous. Gene Structure: Family of Genes. Diunduh dari http://mol-biol4masters.masters.grkraj.org/ html/Gene Structure2-Family of Genes.ht $\underline{\mathrm{m}}$

13. Elizabeth G and Marry Ann TJA, 2010. Genotype-Phenotype Diversity of Beta-Thalassemia in Malaysia: Treatment Options and Emerging Therapies. Medical Jurnal Malaysia, 65: 256-260.

14. Mosca A, Paleari R, Leone D, and Ivaldi G, 2009. Hemoglobin $F$ measurement in the diagnosis of thalassemia and related hemoglobinopathies. Clinical biochemistry, 42: 1797-1801.

15. Sankaran VG and Orkin SH, 2012. The Switch from Fetal to Adult Hemoglobin. Cold Spring Harbor Perspective in Medicine [Online].

16. Wang WC. n.d. Hemoglobinopathies. Memphis: Department of Hematology/Oncology St. Jude Children's Research Hospital.

17. Olufemi AE, Sola, OB, Oluwaseyi B, Ajani RA, Olusoji MO, and Olubunmi HR, 2011.
Hemoglobin $\mathrm{F}$ level in different hemoglobin variants. The Korean Journal of Hematology, 46:118-122.

18. Harteveld CL and Higgs DR, 2010. $\alpha$-thalassemia. Orphanet Journal of Rare Diseases, 5: 1-21.

19. Galanell R and Origa R, 2010. Beta-thalassemia. Journal of Rare Diseases, 5: 1-15.

20. Weatherall DJ, 1983. The Diagnostic Features of the Different Forms of Thalassemia. In: Weatherall, D. J. (ed.) The Thalassemias. London Melbourne New York: Churchill Livingstone.

21. Cappellini MD, 2012. The Thalassemias. In: Goldman, L. \& Schafer, A. I. (eds.) Cecil Medicine. 24th ed. New York.

22. Hoppe CC, 2009. Newborn screening for non-sickling hemoglobinopathies. Hematology, p:19-25.

23. Kohne E and Kleihauer E, 2010. Hemoglobinopathies: A Longitudinal Study Over Fur Decades. Deutsches Arzteblatt, 107: 65-71.

24. Bouva MJ, Mohrmann K, Brinkman HBJ, Kemper-Proper EA, Elvers B, Loeber JG, Verheul FEAM, and Giordano PC, 2010. Implementing neonatal screening for hemoglobinopathies in the Netherlands. Journal of Medical Screening 17: 58-65.

25. Anonymous. Overview \& Epidemiology Thalassemia. Diunduh dari http://www.ironhealthalliance.com/disease -states/thalassemia.

26. Kotila TR, Adeyemo AA, Mewoyeka OO, and Shokunb AA, 2009. Beta thalassaemia trait in Western Nigeria. African Health Sciences, 9: 46-48.

27. Baig SM, Rabbi F, Hameed U, Qureshi JA, Mahmood Z, Bokhari SH, Kiani A, Hasan H, Baig JM, Azhar A, and Zaman T, 2005. Molecular characterization of mutations causing B-thalassemia in Faisalabad Pakistan using the amplification refractory mutation system (ARMS-PCR). Indian Jurnal of Human Genetics, 11: 80-83.

28. Fucharoen S and Winichagoon P, 2007. Prevention and Control of Thalassemia in Asia. Asian Biomedicine 1: 1-6.

29. Rozitah R, Nizam MZ, Nur Shafawati AR, Nor Atifah MAMD, Kannan TP, Arifin $M$, Norsarwany $M$, Setianingsih I, Harahap A and Zilfalil BA, 2008. Detection of beta-globin gene mutations among Kelantan Malay thalassaemia patients by 
ISSN 1978-2071 (Print); ISSN 2580-5967 (Online) Jurnal Ilmiah Kedokteran Wijaya Kusuma 5(2) : 33-43

polymerase chain reaction restriction fragment length polymorphism. Singapore Medical Journal, 49: 1046-1049.

30. Greenberg PL Gordeuk V, Issaragrisil S, Siritanaratkul N, Fucharoen S, and Ribeiro RC, 2001. Major hematologic diseases in the developing world- new aspects of diagnosis and management of thalassemia, malarial anemia, and acute leukemia. Hematology Am Soc Hematol Educ Program, p: 479-498.

31. Sofro ASM, Clegg JB, and Madiyan M, 1993. Frekuensi Trait Thalassemia-B Di Maumere, Flores. Berita Kedokteran Masyarakat, IX.

32. Sofro ASM, Clegg JB, Abuthan R, Madiyan $M$, Tasmini and Hastuti $P, 1994$. Frekuensi Trait Thalassemia-B di Ujung Pandang, Sulawesi Selatan. Berita Kedokteran Masyarakat, $\mathrm{X}$.

33. Sofro AM and Clegg JB, 1994. Frekuensi Trait Thalassemia-B di Ambon, Maluku. Berita Kedokteran Masyarakat, X.

34. Setianingsih I, Williamson R, Marzuki $S$, Harahap A, Tamam M, and Forrest S, 1998. Molecular basis of $\beta$-thalassemia in Indonesia: Application to prenatal diagnosis. Molecular Diagnosis, 3: 11-20.

35. Setianingsih I, Williamson R, Daud D, Harahap A, Marzuki S, and Forrest S, 1999. Phenotypic variability of Filipino $\beta^{\circ}$-thalassemia/HbE patients in Indonesia. Hematology, 62: 7-12.

36. Untario S, 1988. Trait of thalassaemia and haemoglobin E in Surabaya, Indonesia. Trop Geogr Med, 40: 128-130.

37. Tan JA, Tay JS, Soemantri A, Kham SK, Wong HB, Lai PS and Saha N, 1992. Deletional types of alpha-thalassaemia in central Java. Hum Hered, 42: 289-292.

38. Sofro AS, 1995. Molecular pathology of beta-thalassemia in Indonesia. Southeast Asian J Trop Med Public Health, 26 Suppl 1: 221-224.

39. Ganie RA, 2008. Distribusi Pembawa Sifat Thalassemia $(\alpha \quad \& \quad \beta)$ dan Hemoglobin-E pada Penduduk Medan. Majalah Kedokteran Nusantara, 41.

40. Setianingsih I, Harahap A, and Nainggolan IM, 2003. Alpha Thalassemia in Indonesia: Phenotype and Molecular Defects. In: Marzuki, S., dkk. (eds.) Tropical Diseases. New York: Kluwer Academic/Plenum.

41. Atmakusumah TD, Wahidijat PA, Sofro AM, Wirawan R, Tjitrasari T, Setianingsih I, and Wibawa A, 2010. Pencegahan Thalassemia (Hasil kajian HTA tahun 2009). Jakarta:
Dirjen Bina Pelayanan Medik Kementrian Kesehatan Indonesia. 